\title{
Consumer Valuation Of Higher Education And Adjusted Rates Of Return
}

\author{
Dr. Stephanie Owings-Edwards, (E-mail: owings_s@fortlewis.edu), Fort Lewis College
}

\begin{abstract}
This paper regards higher education as a bundle of services. This approach yields a rate of return which is between $0.5 \%$ and $4.1 \%$ higher than previously calculated. This paper makes use of data which shows how much students actually paid to attend college, a value which is often very different than the stated tuition. When students purchase the college bundle they are buying labor market skills, intellectual stimulation, a peer-group, socializing opportunities and a network of contacts. I identify which elements of the education bundle consumers wish to purchase. If a consumer purchases a good which enhances his income that purchase can be regarded as an investment. Otherwise it is regarded as a consumption good. Using a standard wage equation, which includes the elements of the education bundle consumers are willing to purchase, I confirm there are both consumption and investment aspects to the purchase of higher education. This implies previous rate of return calculations underestimated the investment return on a college education.
\end{abstract}

\section{INTRODUCTION}

Typically, one can deduce the value the consumer places on a good by observing its price. The higher price a good can command the greater must be the worth the consumer attaches to it.

When the commodity in question is higher education, however, the price the consumer pays for the good is not easily observed. Only a fraction of the students attending a college pay the stated tuition. Scholarships, financial aid, and loans are all available from both the institution and other outside sources. Because of this, one cannot deduce from tuition alone the value students place on the product the school provides.

I begin this paper by investigating for what consumers of higher education are willing to pay. I am not trying to establish a single equilibrium price for college education; I am not trying to construct an aggregate demand and supply curve. I am simply examining what elements of higher education attract the consumer's dollar.

A college education is a bundled good. The consumer is purchasing schooling. It may be schooling for the sake of knowledge or the acquisition of skills which will be of value in the labor market. In addition, the consumer is purchasing an environment. Schools differ in the social opportunities which are available. They differ in the amount and quality of spectator sporting diversions which are provided. Some schools provide fellow students who are academically gifted. Others provide an environment where networking skills can be practiced and connections can be made. This paper explores which of these separate components of the total college bundle the consumer values.

Once this is determined, I test to see which of these valued components the labor market is willing to reward. To the extent consumers are purchasing items which do not yield a higher income, one can deduce a consumption motivation to their purchase. When considering the purpose of higher education purchases, the discussion of the last 30 years debated whether college education builds human capital or serves as a productivity signal. This paper tests if there exists a third, neglected, motivation to the purchase of higher education: consumption. It concludes that a college education is, in part, a consumption good.

The data used in this paper comes from the survey High School and Beyond. One of the unusual features of this data set is it includes both how much a student paid, out-of-pocket, to attend a specific college and how much his parents 
contributed. This sum is the price the consumer actually paid for a college education. Using this price as a dependent variable and a vector of independent variables which include college characteristics, I can identify elements of the college-education-bundle which attract the consumer's dollar. Once these elements have been identified, I insert them in a wage equation. If they do not significantly affect wage then we have identified a consumption aspect to college education.

The organization of this paper is as follows: Section II reviews what scant literature exists on the consumption aspects of higher education purchases. Section III details the sample from which I draw my empirical data. Section IV outlines the model used to determine for which aspects of the education bundle consumers are willing to pay. Empirical results from the model outlined in Section IV are described in Section V. Section VI tests to determine which elements of the college bundle are pure consumption goods and which have investment components. Rate of return calculations are performed in Section VII. Section VIII concludes.

\section{LITERATURE REVIEW}

There has been considerable effort expended in developing a demand function for higher education ${ }^{1}$. Much of the work has been done at the aggregate level. Typically, the enrollment rate in higher education institutions is taken as the dependent variable and its performance is tracked over time. Sometimes, rather than observing the percentage of the population which has enrolled in post-secondary education, a logit model is formed using non-aggregate data. In these cases, each individual's choice regarding whether to attend a post-secondary institution is the dependent variable.

Most higher education demand analysis done after Gary Becker's Human Capital focused on the investment aspects of demand. Consumers forgo current income in order to obtain an education which will yield a higher stream of lifetime earnings. Demand for higher education depends on the expected value of this higher income stream. Prior to Becker's work, the main emphasis of research had been directed toward determining the non-pecuniary benefits of education. That higher education is purchased, in part, for its consumptive value is a notion which has been largely ignored for the last 30 years. ${ }^{2}$

Blaug launched a vitriolic attack on human capital theory in 1976. He dissects some early models which purport to support the human capital theory and suggests they are really much more strongly supportive of higher education being a consumption good. Kodde and Ritzen (1984) developed a theoretical model which integrated consumption and investment motives in the explanation of higher education demand. They showed demand for higher education is greater when a consumption motive is included in addition to the investment motive. Lazear (1977) considered an individual's background and ability, estimated the cost of higher education and calculated the rate of return to schooling. His calculations indicated individuals obtain less schooling than is required for wealth maximization. From this he concluded that higher education, as a consumption commodity, is a bad ${ }^{3}$. Thus, not only have the consumption aspects of higher education been largely ignored, there is no consensus among those few who have done consumption work.

\section{THE DATA SET}

The primary data set used in this study is a sub-sample of the fourth follow-up of High School and Beyond. This study, administered by the U.S. Department of Education, began in 1980, collecting data from over 30,000 high school sophomores. The fourth follow-up study contacted 14,825 members of the original sophomore cohort. The High School and Beyond data set includes information concerning how much a student paid to attend a specific college and how much financial assistance he received from his parents while he was enrolled in the school. This allowed for the construction of the dependent variable, "Annual Payments." Other individual specific information (such as the

\footnotetext{
${ }^{1}$ See Becker, W.E. (1990) for an extensive review of higher education demand analysis.

${ }^{2}$ Kodde and Ritzen (1988), pg. 357, and Becker, W.E. (1990), footnote 1, both acknowledge this.

${ }^{3}$ Lazear implicitly assumes agents are risk neutral. If agents are risk averse and the expected earnings stream is uncertain, it would be expected they underinvest in education. Risk averse agents are unwilling to pay the full expected value for an uncertain stream of earnings. The presence of risk aversion undermines his contention education is a bad.
} 
individual's academic performance in high school, his family's income level, his parent's educational attainment, race and sex) is also found in High School and Beyond.

Although High School and Beyond identified the college(s) an individual attended it did not include college specific data. This data was collected from a variety of sources. See "Data Sources" in the bibliography for details.

\section{THE VALUATION MODEL}

There are a variety of elements in the education bundle for which consumers may be willing to pay. Nonetheless, price is not determined exclusively by what the family is willing to pay. Given that schools do indeed price discriminate, factors which the college considers in making their pricing decision should also be included as independent variables. Thus, the following equation is to be estimated:

$\operatorname{Ln}(S)=a+b_{i} X_{i}+c_{i} Y_{i}+u$

$\mathrm{S}=$ direct family spending on education.

$X_{i}=$ a vector of college characteristics for which the family may be willing to pay

$\mathrm{Y}_{\mathrm{i}}=\mathrm{a}$ vector of individual attributes which might induce a college to offer a price discount

$\mathrm{u}=$ disturbance term

Each of these variables is described in more detail below.

\section{Dependent Variable}

The dependent variable is the natural log of the annual amount paid by the family for schooling expenses. It was created by summing together the amount the student and his parents paid for every year he attended a specific institution and then dividing by the number of years he was at that institution. It represents a floor; the family is willing to pay at least that much to send the student to school. It could be they would have been willing to pay more but the college did not require it.

\section{College characteristics for which the family may be willing to pay:}

Research expenditures per faculty member captures the research orientation of the school. The larger its value the greater the research emphasis of the school. Litten and Hall (1989) analyzed a survey of 236 high school seniors and their parents in an attempt to define what constitutes a quality college in the opinion of the purchasers of the good. Both the seniors and their parents identified a faculty which devotes a high degree of effort to teaching rather than research as a very important indicator of the quality of the college. Thus a negative coefficient is predicted for the research expenditures per faculty member variable.

Greek organizations per student measures the degree of participation in social fraternities and sororities. It sums together the number of NIF chapters (social fraternities), the number of NPC chapters (social sororities), and the number of NPHC (black social fraternities and sororities) on each campus. This value is divided by the undergraduate enrollment to create a variable approximating PanHellenic involvement per student.

Whether a college is publicly or privately controlled clearly affects its stated tuition. According to the Digest of Education Statistics, in 1982 the tuition and fees at four-year public institutions averaged \$1,031 whereas they averaged $\$ 4,639$ at private four-year schools. However, those figures don’t take into consideration financial aid the students may have received. With this data set we have the advantage of knowing what students actually paid as opposed to the stated tuition. The model estimated in this paper includes 4 control variables: public institution, private non-sectarian college, Catholic college, and Protestant college. These variables allow us to determine if students and their families are really willing to pay more, out of pocket, to attend a non-public institution. 
The variable "Post-Season Sports Appearances" attempts to capture the quality of spectator sporting entertainment a school provides. It sums together the number of football bowl appearances the school made between 1972 and 1981 (the decade prior to when the student made his schooling choice) and the number of NCAA Division I Basketball Tournament games the school won over this period. If the school was the National Champion in either of these sports in any year in this time period an extra point was added to their total. For the years in which the NCAA Basketball Tournament granted some schools first round byes, the schools granted such a bye were credited with a win.

The average SAT score attained by the undergraduates at each particular university proxies the academic potential of the student body. The more able the student body the more demanding the coursework. This environment may be something students and their families want to purchase.

\section{Individual attributes which might induce a college to offer a price discount:}

The family's income in 1982 is included in the model. Students from low income families qualify for needbased assistance thereby lowering the amount they have to pay out of pocket. Without financial assistance, a lower income level would leave a family less able to pay for education. Both of these factors would lead to a positive coefficient.

"Parent's Education Level" is a categorical variable classifying the highest level of education attained by either of the student's parents. The higher the level of education attained the larger the variable. A positive coefficient is anticipated. The theory is, having acquired a college education themselves, parents are more willing to pay for a child's education.

"High School GPA" is a categorical variable indicating the grades the individual earned in high school. The smaller the value the higher the grades the student earned. The variable's sign is a priori ambiguous. A student who earned high grades in high school may be able to command a price discount from a college. If this is the case, "High School GPA" would be positive. Conversely, a student who earned high grades in high school may value education more highly and thus be willing to pay more for an education. In this instance "High School GPA" would be negative.

"Non-white" is a dummy variable which takes the value 1 if the individual is non-white. This variable is expected to be negative. Aid based on minority status is available. This would lead to a decrease in out-of-pocket costs of attending college for minorities.

The percentage of students who dropped out of the high school the student attended is a proxy for neighborhood. The higher this value the smaller the emphasis the student will tend to place on education; (s)he has been immersed in an environment which does not value education. Thus a negative relationship between "Percent of High School Cohort that Dropped-out" and the price the student's family paid is postulated.

The "Female" variable takes the value of 1 if the individual is a woman. It's anticipated that this variable will be insignificant. But if colleges recruit women via price discounting it will be negative and significant. If women do not value education as highly as men then the coefficient will also be negative and significant.

\section{VALUATION REGRESSION RESULTS}

Table 1 (found at the back of the paper) describes the valuation regression results where the dependent variable is the natural $\log$ of direct family spending on education per year. The results indicate families are willing to pay a premium to send the student to a college with a high average SAT score. For every 100 point increase in a school's average SAT score the family paid an extra 9\%. They also seem willing to pay an additional sum to send the student to a school with a winning sports program. An extra 10 post-season game appearances increases the amount a family paid by $10 \%$. Families are not, however, willing to pay a premium in order for the student to attend a school with an active PanHellenic environment. The control of the school (private non-sectarian, private Christian, and private Catholic) clearly matters tremendously to the purchasers of higher education. They are willing to pay up to $50 \%$ more to attend one 
of these institutions. Two schools with identical average SAT scores and with identical sports records but which differ in control (one being private, one being public) are valued very differently by consumers.

Family income is very significant and positive, as predicted. The high school GPA coefficient indicates those students who do well in high school value education and are willing to pay more for it. Holding income and high school GPA constant, "Non-white" and "Female" are both significant and negative. This suggests women and minorities are either the beneficiaries of aid based on their status or that they value education less highly. "Percent of High School Cohort Who Dropped Out" serves to proxy the neighborhood attitude toward education. As predicted, growing up in an environment which does not value education makes an individual less willing to pay for education.

Research Expenditures per Faculty Member is insignificant. Families do not seem willing to pay a premium for a student to attend a research oriented university. The Litten and Hall study, which suggested the inclusion of the research variable and predicted it would have a negative value, used a data set which was limited to students who had done very well on the Preliminary Scholastic Aptitude Test (combined score of 113 or more and with a score of at least 50 on both tests). Here I use a much broader data set which includes anyone who went to college. Although students in the top academic performance percentiles, like those in the Litten and Hall study, may choose a college based on the degree of faculty attention which they receive, most college students apparently do not. Casual observation of the college guide industry supports this conclusion. Guides such as Barron's Profiles of American Colleges do not include information regarding the emphasis a school places on research. Since publication of college guides appears to be a fairly competitive industry, this suggests that the mainstream student is not interested in knowing the level of research performed by a school's faculty.

\section{INVESTMENT OR CONSUMPTION?}

Many goods have both consumption and investment characteristics. For instance, the purchase of a home serves both as an investment and yields a stream of consumption services. Section IV considered the bundle of services that college provides and identified for what elements consumers are willing to pay. But simply because a consumer is willing to pay for a good does not make it a consumption good. In this section I test to see which of these goods display pure consumption characteristics and which have at least some investment qualities.

If an element in the bundle of services which college provides does not affect the income an individual earns after leaving college then it can be considered a pure consumption good. A variable from the bundle which does impact on later earnings is, at least to some degree, an investment good. That is, by purchasing that element in the college education bundle the student has secured future earnings rewards.

There is a significant body of literature which debates whether a college education acts to build human capital or whether it acts as a screening device, identifying more able individuals for potential employers. Regardless of which of these hypothesis is correct, the purchase of a service which enhances income will constitute an investment. That is, if an element of the college bundle enhances human capital and, as a result, increases future income then its purchase would be an investment. Conversely, if an element of the college bundle is purchased to signal to the employer the applicant's productivity and as a result increases the applicant's future income, then its purchase would be an investment.

\section{The Model}

The empirical work in this section is based on human capital theory. A standard wage equation is estimated. Included as independent variables are all of the elements of the consumption bundle which were identified in Section IV as being components for which students are willing to pay. In addition, the model's dependent variable, logarithm of annual wage, is theorized to depend on:

\footnotetext{
- occupation

- $\quad$ workforce/job experience

- $\quad$ current employment/schooling status

- $\quad$ family background

- $\quad$ individual ability

- $\quad$ race/gender
} 
Exact definitions of each of the variables is found in Appendix 1. Table 2 displays the regression results (both of these are found at the back of the paper).

Post-season sports appearances is insignificant. Attending a school which provides excellent spectator sporting entertainment in no way affects the income a student will earn after leaving college. The sports entertainment element in the college bundle is a pure consumption good.

Attending a private or Catholic college did not have a statistically significant impact on income. Attending a Protestant institution negatively impacted earning power. Apparently those enrolled at Protestant colleges had other, nonincome related, goals. Regardless, attending a private, Catholic, or Protestant school cannot be regarded as an investment choice (at least in the corporal realm).

Students who attend colleges with high average SAT scores can anticipate earning a wage premium as a result. This indicates there is an investment motive prompting the purchase of this element in the college bundle. It does not exclude the possibility that this good serves as a consumption product as well. That is, students may both enjoy attending a college where there are many of bright students and they may earn a higher wage as a result. All that can be said with certainty is an element in the college bundle which is not a pure consumption good has been identified.

\section{RATE OF RETURN}

Typically, when calculating the rate of return to education, the cost of the additional schooling is compared to the wage premium it generates. However, as was established in the previous sections of this paper, there is a consumption component to the education bundle that many consumers purchase. Thus, any rate of return calculation which is based on what consumers paid for a year's worth of schooling will underestimate the return to educational investment; only a fraction of the dollars spent on schooling represent investment expenditures.

Determining a rate of return, a priori, is always a somewhat rough approximation. However, it is useful to perform some "back of the envelope" calculations in order to get an idea of the magnitude of the effect of separating the investment and consumption components of the education bundle.

To calculate what an "average student" paid for a year's worth of education, net of a consumption component, I return to the valuation model estimated in Section IV. The model is re-estimated based on college-graduate-only data (available wage premiums compare high school and college graduates). Using the re-estimated coefficients, setting postseason sports appearances, private, Catholic, and Protestant college attendance all equal to zero, and setting all other variables at their mean values, yields an annual payment of $\$ 2669$. That is, an average student who graduated from a public college that had no post season sports appearances paid \$2669 for a year of college education.

In 1992, the year individuals in this data set were asked to report their income, a high school graduate's median income was $\$ 28,921$ and a college graduate's median income was $\$ 49,381$. That is, the college wage premium equaled $\$ 20,460$. Assuming

- $\quad$ students took 4 years to complete their degree

- $\quad$ students did not work while they were in college (i.e. they chose to forego the $\$ 28,921$ they could have earned as a high school graduate)

- $\quad$ the college wage premium of $\$ 20,460$ persists over a 40 year working life-span

then the internal rate of return for an average student who graduated from a public college that had no post-season sports appearances was $13.22 \%$.

Using the same methodology as above, a student who chooses to purchase a private, non-secular, education and attends a school with an average number of post-season appearances will pay $\$ 4218$ for a year's worth of education. This results in an internal rate of return of $12.68 \%$. That is, by erroneously including consumption goods (private school attendance and post-season sports entertainment) in rate of return calculations, the return on the investment fraction of 
the education purchase is underestimated by more than $0.5 \%(13.22 \%-12.68 \%)$. The results are almost identical if the student chose to attend a Catholic college.

Recall that attending a private Protestant college has a statistically significant and negative impact on income. Thus, the life-long wage premium which accrues to a college graduate must be reduced by $30 \%$. As a result, the internal rate of return for a student who chooses to purchase a private Protestant education and attends a school with an average number of post-season appearances is $9.12 \%$.

An average student in all respects except that (s)he chooses to attend a school with 5 additional post-season sports appearances (a little less than 1 standard deviation from the mean) will pay $\$ 3256$ per year to attend that school. This purchase of sporting entertainment lowers the calculated internal rate of return to $13.01 \%$.

Table 3 (found at the back of the paper) summarizes the internal rate of return calculations. These results suggest internal rate of return calculations underestimate the true return on investment between $0.5 \%$ and $4.1 \%$ depending on which combination of consumption goods were purchased. This range is actually conservative. The implicit assumption is that items, such as a school's average SAT score, which have a statistically significant, positive, impact on income are pure investment goods. However, this need not necessarily be true. A student may be willing to pay extra to attend a school with a high average SAT score because of the scholastic environment this provides regardless of the effect it has on income.

\section{CONCLUSION}

The literature of the last 30 years gave no real consideration to the consumption aspects of higher education. This study has shown families are willing to pay for elements of the college bundle which yield no income premium. That is, there are elements in the college bundle for which consumers are willing to pay but which have no investment component. These elements must be considered to be consumption goods: goods which consumers purchase because they yield utility. Thus the screening or human capital debate, which gives us a binary choice concerning the role of college education, has incorrectly phrased the question. Consumers neither purchase education exclusively to develop human capital nor do they purchase education solely to signal their productivity to an employer. Higher education institutions are selling, at least in part, a consumption good.

This may explain what could otherwise only be regarded as a paradox: specifically, the contention on the part of academics that the price a school charges is unrelated to the quality of the product which it provides. For instance, Thomas Sowell contends:

"With colleges and universities, even the prices charged are not nearly as indicative of quality as the prices charged for most goods and services. According to a Carnegie Foundation Study 'substantial differences in costs do not necessarily connote significant differences in outcomes'... Some very mediocre institutions charge high tuition and some top-rated institutions charge much less."

But this begs the question "How can mediocre schools charge high tuition?" Who would be willing to pay a great deal for a mediocre product when a higher quality good could be had for less? The answer would seem to be, although academics may consider the product mediocre, the actual consumers do not. Perhaps the academics, immersed in the screening/human capital debate, have focused exclusively on the investment component of the higher education purchase. Consumers, when considering the consumption value and the investment value associated with particular institution, deem the price charged to fairly reflect the value of the product they are purchasing.

The determination of a consumption aspect to higher education purchases does not necessarily imply a change in educational policy. There are many consumption goods whose purchase the government subsidizes. However, because part of the purchase price reflects the consumptive value of the good, the rate of return on the investment fraction of the government's dollar is actually higher than previously calculated. 


\section{REFERENCES}

1. Becker, Gary S. Human Capital, 3rd Ed. Chicago: University of Chicago Press, 1993.

2. Becker, William E. "The Demand for Higher Education" in Stephen Hoenack and Eileen L. Collins, eds., The Economics of American Universities. Albany, NY: State University of New York Press, 1990.

3. Blaug, Mark. "The Empirical Status of Human Capital Theory: A Slightly Jaundiced Survey". Journal of Economic Literature, 1976, 14(3), pp. 827-855.

4. Clotfelter, Charles T. and Rothschild, Michael. "Studies of Supply and Demand in Higher Education. Chicago": The University of Chicago Press, 1993.

5. Clotfelter, Charles T. "Demand for Undergraduate Education" in C.T. Clotfelter, R.G. Ehrenberg, M. Getz and J.J. Siegfried, eds., Economic Challenges in Higher Education. Chicago: The University of Chicago Press, 1991.

6. Freeman, Richard B. "Demand for Education" in Orley Ashenfelter and Richard Layard, eds., Handbook of Labor Economics vol. 1. New York, NY: Elsevier Science Publishers, 1986.

7. James, Estelle. "Product Mix and Cost Disaggregation: A reinterpretation of the Economics of Higher Education". The Journal of Human Resources, 1978, 13(2), pp. 157-186.

8. Kodde, David A. and Ritzen, Jozeff M.M. 1984. Integrating Consumption and Investment Motives in a Neoclassical Model of Demand for Education. Kyklos, 1984, 37, pp. 598-607.

9. . "Direct and Indirect Effects of Parental Education level on the Demand for Higher Education". The Journal of Human Resources, 1988 23(3), pp. 356-372.

10. Lazear, Edward. “Education: Consumption or Production?” Journal of Political Economy 1977, 85(3), pp. 569597.

11. Litten, Larry H. and Hall, Alfred E. "In the Eyes of our Beholders: some evidence on how high-school students and their parents view quality in colleges". Journal of Higher Education, May/June 1989, 60, pp. 302-324.

12. Sowell, Thomas. Inside American Education. New York: The Free Press, 1993.

13. U.S. Department of Education. 1997. Digest of Education Statistics. Washington: Government Printing Office.

\section{DATA SOURCES}

Anpay, Tsat, Clstand, Fy111, Academ, Ped, Sex, Race, Sb014, Private, Catholic:

High School and Beyond. U.S. Dept. of Education. 1992.

Sport:

McCallum, J.D. College Basketball, USA. New York: Stein and Day, 1978.

Savage, Jim. The Encyclopedia of the NCAA Basketball Tournament. New York: Del Publishing, 1990.

The World Almanac Book of Facts. New Jersey: Newspaper Enterprise Association, 1995.

Greek:

Baird, W.R., J.L. Anson, R.F. Marchesani. Baird's Manual of American College Fraternities. Indianapolis, Ind.: Baird's Manual Foundation, 1991.

Research Expenditures By College In 1982, College Control:

U.S. Dept. of Education. Higher Education and General Information Survey (HEGIS). Washington D.C., 1983.

Institutional Avg Sat Scores. Faculty Size:

American Council on Education. American Universities and Colleges. New York: American Council on Education, 1983.

Act To Sat Conversions:

Langston, I.W. Research Memorandum 87-4: SAT-ACT Equivalents. University Office of School and College Relations, University of Illinois, 1987. (Supplied by ACT, Iowa City, Iowa) 
Table 1

\begin{tabular}{|c|c|}
\hline I ndependent Variable & $\begin{array}{l}\text { Dependent Variable = } \\
\text { In (annual payments) }\end{array}$ \\
\hline Intercept & $6.46(.269))^{\star \star \star}$ \\
\hline High School GPA & $-.043(.023)^{\star}$ \\
\hline Family Income & $.118(.014)^{* \star \star}$ \\
\hline Non-white & $-.176(.099){ }^{*}$ \\
\hline Female & $-.095(.051)^{\star}$ \\
\hline$\%$ of High School cohort that dropped-out & $-.006(.003)^{\star}$ \\
\hline Parent's Education level & $.009(.011)$ \\
\hline Post-Season Sports Appearnaces & $.010(.006){ }^{\star}$ \\
\hline Greek Organizations/Student Body Enrollement & $-7.39(11.1)$ \\
\hline Private, non-sectarian, college & $.514(.090))^{* * \star}$ \\
\hline Catholic college & $.424(.110)^{* * *}$ \\
\hline Protestant college & $.544(.112) * \star \star$ \\
\hline Average Undergrad SAT & $.0009(.0003){ }^{* \star \star}$ \\
\hline Research Expenditures/Faculty & $.002(.001)$ \\
\hline Adjusted R-squared & 0.2872 \\
\hline $\mathrm{N}$ & 714 \\
\hline
\end{tabular}

$*=$ statistically significant at the .10 level

$* *=$ statistically significant at the .05 level

$* * *=$ statistically significant at the .01 level standard error in parentheses 
Table 2

\begin{tabular}{|c|c|}
\hline Independent Variables & $\ln ($ wage $)=$ dependent variable \\
\hline Intercept & $6.36(.451) * * *$ \\
\hline Currently unemployed & $-.421(.108) * * *$ \\
\hline Currently in school & $-.381(.076) * * *$ \\
\hline Individual SAT score & $.0002(.0002)$ \\
\hline Individual undergraduate GPA & $.008(.053)$ \\
\hline Individual High School GPA & $.015(.029)$ \\
\hline Hispanic & $.157(.150)$ \\
\hline Black & $.203(.123) *$ \\
\hline Asian & $.128(.209)$ \\
\hline Has a Graduate Degree & $-.090(.087)$ \\
\hline Proportion of months employed since 1982 & $.014(.003) * * *$ \\
\hline College Education Helpful in getting current job & $.158(.054) * * *$ \\
\hline Highest Level of Education attained by either parent & $-.025(.011) * *$ \\
\hline Years of experience at current job & $.034(.012) * * *$ \\
\hline Percent of drop-outs from high school & $-.001(.004)$ \\
\hline Female & $-.383(.055) * * *$ \\
\hline Occupation engineering professional & $.041(.134)$ \\
\hline Occupation manager & $.320(.070) * * *$ \\
\hline Occupation medical professional & $.148(.114)$ \\
\hline Occupation legal professional & $.071(.172)$ \\
\hline Occupation other professional & $.050(.100)$ \\
\hline Occupation sales & $.187(.097) *$ \\
\hline Occupation school teacher & $.117(.125)$ \\
\hline Occupation computer & $.442(.129) * * *$ \\
\hline Occupation non-computer technical & $-.252(.159)$ \\
\hline Occupation physician & $.212(.235)$ \\
\hline Has a Bachelor's Degree & $.273(.061) * * *$ \\
\hline Family Income in 1982 & $.033(.014) * *$ \\
\hline College-wide average SAT & $.0009(.0003) * * *$ \\
\hline Post-Season Sports Appearances & $.005(.005)$ \\
\hline Attended a private, non-sectarian, college & $.141(.088)$ \\
\hline Attended a private, Catholic, college & $.095(.111)$ \\
\hline Attended a private, Protestant, college & $-.299(.121) * *$ \\
\hline Adjusted R-squared & 0.1973 \\
\hline $\mathrm{N}$ & 1291 \\
\hline
\end{tabular}

$*=\quad$ statistically significant at the .10 level

$* *=\quad$ statistically significant at the .05 level

$* * *=$ statistically significant at the .01 level

standard error in parentheses 
Table 3

\begin{tabular}{|l|l|l|l|r|}
\hline \multicolumn{5}{|c|}{ Rate of Return College Graduates Earn on Their Schooling Investment } \\
\hline Education Bundle & $\begin{array}{l}\text { Foregone } \\
\text { Earnings/Year } \\
\text { while in college }\end{array}$ & $\begin{array}{l}\text { Average Price Paid } \\
\text { for 1 Year's } \\
\text { Education }\end{array}$ & $\begin{array}{l}\text { Post College } \\
\text { Earnings } \\
\text { Premium }\end{array}$ & Rate of Return \\
\hline $\begin{array}{l}\text { Public College: No post- } \\
\text { season sports } \\
\text { apparances }\end{array}$ & $\$ 28,921$ & $\$ 2,669$ & $\$ 20,460$ & $13.22 \%$ \\
\hline $\begin{array}{l}\text { Private, non-secular } \\
\text { college: Post-season } \\
\text { sports appearances } \\
\text { mean }\end{array}$ & $\$ 28,921$ & $\$ 4,218$ & $\$ 20,460$ & $12.68 \%$ \\
\hline $\begin{array}{l}\text { Catholic college: Post } \\
\text { season sports } \\
\text { appearances = mean }\end{array}$ & $\$ 28,921$ & $\$ 4,197$ & $\$ 20,460$ & $12.69 \%$ \\
\hline $\begin{array}{l}\text { Protestant college: Post- } \\
\text { season sports } \\
\text { appearances }=\text { mean }\end{array}$ & $\$ 28,921$ & & $\$ 14,322$ & \\
\hline
\end{tabular}

\section{APPENDIX 1}

\section{Dependent Variable}

The dependent variable is the natural $\log$ of the wage an individual was earning in 1992. All individuals in the sample attended, although did not necessarily graduate from, college. They were all high school sophomores in 1980, and, as a result are essentially the same age.

\section{Current employment/Schooling status}

- $\quad$ College education helpful in getting current job: dummy variable set equal to 1 if, when interviewed in 1992, the individual indicated he would not have been able to get his current job without the education he had received since high school.

- Currently in-school: dummy variable equal to 1 if, when interviewed in 1992, the individual was taking undergraduate or graduate classes.

- $\quad$ Currently unemployed: dummy variable equal to 1 if, when interviewed in 1992, the individual was not working full-time or part-time, or was temporarily laid-off.

- Has a Bachelor's Degree: dummy variable equal to 1 if the individual attained a bachelor's degree

- Has a Graduate Degree: dummy variable equal to 1 if transcripts indicated the student had earned a master's, doctorate or professional degree. This dummy is also set equal to 1 if the student indicated he had received a master's, doctorate or professional degree, in contradiction to his transcript record, and the survey did not receive all of the transcripts requested. 


\section{Family Background}

- $\quad$ Family income in 1982: A categorical variable where higher categories correspond to higher levels of income

- $\quad$ Highest level of education attained by either parent: a categorical variable indicating the highest level of education achieved by either parent. The greater the variable the higher the level of education attained. The parent's separate levels of education were combined into this one variable due to the high number of missing observations on one of the parents.

- $\quad$ Percent of drop-outs from high school: percent of students who dropped out of the high school the individual attended

\section{Individual Ability}

- Individual high school GPA: categorical variable indicating the grades the individual earned in high school. The smaller the value the higher grades the student earned

- Individual SAT score: score earned on the SAT or, if the SAT was not taken, score earned on the ACT converted into its SAT value.

- Individual undergraduate GPA: total undergraduate GPA. This is based on a 0-4.0 scale.

\section{Occupation}

An individual could identify him(her)self as having one of 29 different occupations. In this sample 30-35\% of the individuals had occupations other than those captured by the dummy variables.

- Occupation computer: dummy variable equal to 1 if the individual's 1992 occupation is computer related, technical

- Occupation engineering professional: dummy variable equal to 1 if the individual's 1992 occupation is engineering professional

- Occupation legal professional: dummy variable equal to 1 if the individual's 1992 occupation is legal professional

- Occupation manager: dummy variable equal to 1 if the individual's 1992 occupation is government management, sales management, retail management, manufacturing management, or other management

- Occupation medical professional: dummy variable equal to 1 if the individual's 1992 occupation is medical professional

- $\quad$ Occupation physician: dummy variable equal to 1 if the individual's 1992 occupation is physician

- Occupation other professional: dummy variable equal to 1 if the individual's 1992 occupation is other professional

- $\quad$ Occupation sales: dummy variable equal to 1 if the individual's 1992 occupation is sales

- Occupation teacher: dummy variable equal to 1 if the individual's 1992 occupation is school teacher

- Occupation non-computer technical: dummy variable equal to 1 if the individual's 1992 occupation is noncomputer related, technical

\section{Race/Gender}

- $\quad$ Asian: dummy variable equal to 1 if the individual was Asian

- $\quad$ Black: dummy variable equal to 1 if the individual was Black

- $\quad$ Female: dummy variable set equal to 1 if the individual is female

- Hispanic: dummy variable equal to 1 if the individual was Hispanic

\section{Workforce/Job experience}

- $\quad$ Proportion of months employed since 1982: the proportion of months the individual has been employed since $6 / 82$ (the typical date of high school graduation)

- Years of experience at current job: years experience, broken into twelfths, at the individual's current or most recent job. 